УДК 331.101.3: 33.08

DOI: https://doi.org/10.32851/2708-0366/2020.3.13

Хаврова К.С. кандидат економічних наук, доцент, Донецький національний університет економіки і торгівлі імені Михайла Туган-Барановського ORCID: https://orcid.org/0000-0001-9376-0700

Khavrova Kateryna Donetsk National University of Economics and Trade named after MykhailoTugan-Baranovsky

\title{
РОЛЬ СИСТЕМИ МОТИВАЦІї В СТРАТЕГІЧНОМУ РОЗВИТКУ ПІДПРИЄМСТВ
}

\section{THE ROLE OF MOTIVATION SYSTEM IN STRATEGIC DEVELOPMENT OF ENTERPRISES}

Стаття присвячена аналізу системи мотиваиії персоналу в умовах стратегічного розвитку підприємства. Досліджено процес мотивачї персоналу підприємства за допомогою взаємодії сукупності потреб, мотивів і иілей. Згруповано методи мотивації персоналу підприємства в чотири стимулюючих види, такі як: економічні, управління за цуілями, збагачення праці, система участі. Визначено, щзо система мотивації в стратегічному розвитку підприємства являє собою сукупність взаємопов'язаних елементів та складається із зовнішньої і внутрішньої мотивачії, які повинні бути збалансованими. Визначено, щуо система мотивації повинна містити: мотивацію, спрямовану на підвищення інтелектуального потенціалу; мотивацію, спрямовану на ефективну комунікацію; мотивацію, спрямовану на підвищення компетенцій та мотиваџію, спрямовану на підвищення резульmamiв nраці.

Ключові слова: система мотивації, персонал, зовнішня мотивація, внутрішня мотивація, менеджмент персоналу.

Статья посвящена анализу системы мотивации персонала в условиях стратегического развития предприятия. Исследован процесс мотивацчии персонала предприятия посредством взаимодействия совокупности потребностей, мотивов и иелей. Сгруппировань методы мотивации персонала предприятия в четыре стимулирующих вида, такие как: экономические, управление по целям, обогащение труда, система участия. Определено, что система мотивации в стратегическом развитии предприятия представляет собой совокупность взаимосвязанньх элементов и состоит из внешней и внутренней мотивацчии, которые должны быть сбалансированными. Определено, что система мотивации 
должна содержать мотивацию, направленную на повышение интеллектуального потеничила; мотивацию, направленную на эффективную коммуникацию; мотивачию, направленную на повышение компетенций, и мотивацию, направленную на повыиение результатов труда.

Ключевые слова: система мотивации, персонал, внешняя мотивация, внутренняя мотивация, менеджмент персонала.

The article is devoted to the analysis of the system of personnel motivation in the conditions of strategic development of the enterprise. The process of motivation of the personnel of the enterprise by means of interaction of set of needs, motives and the purposes is investigated. It is proved that the solution to the problem of effective personnel management, first of all, comes down to improving the skills of employees and finding the best ways to motivate employees to work effectively. In view of this, the gradation of potential employees of the enterprise is made: competent and motivated; motivated but not competent enough; competent but insufficiently motivated; insufficiently competent and insufficiently motivated. Methods of motivating the company's staff are grouped into four incentive types: economic (salary in all its forms, including contract, bonuses, benefits, insur-ance, interest-free loans, etc.); goal management (setting a chain of goals for an individual or group, which contribute to solving the main task of the enterprise); labor enrichment (due to non-economic methods, which include: providing people with more meaningful, promising work, significant independence in determining the mode of work and use of resources); system of participation (broad involvement of the team in decision-making on the most important issues of production and management). It is determined that the system of motivation in the strategic development of the enterprise is a set of interconnected elements and consists of external and internal motivation, which must be balanced. External motivation is aimed at encouraging the result and process of intellectual activity. Internal motivation is aimed at creating and maintaining the potential of an intellectual worker. It is determined that the system of motivation should contain: motivation aimed at increasing intellectual potential; motivation aimed at effective communication; motivation aimed at improving competencies and motivation aimed at improving performance. Thus, a comprehensive system of motivation, including internal and external motivation of staff, aimed at creating and applying specialized knowledge, is an effective tool for enhancing the strategic development of the enterprise.

Key words: motivation system, personnel, external motivation, internal motivation, personnel management.

Постановка проблеми. На сучасному етапі розвитку економіки з метою організації якісної та результативної роботи, що спрямована на стратегічний розвиток підприємства, необхідним є мотивування персоналу до ефективної праці. У сучасному менеджменті постає необхідність створення цілісної системи мотивації праці персоналу, яка орієнтована на результативність діяльності підприємства загалом та його стратегічний розвиток.

Аналіз останніх досліджень і публікацій. Визначенням ролі системи мотивації в розвитку підприємстві займалися такі вітчизняні і зарубіжні вчені та фахівці, як: Н.П. Базалійська, М.П. Казановська [1], А.В. Калініченко [2], Л.М. Колот [3], А.В. Корицький [4], А. Сміт [4], Г. Беккер [5], Я. Мінсер [6], Т. Шульц [7] та інші.

Формулювання цілей статті. Відзначаючи широту і глибину проведених досліджень, вважаємо, що досліджень, присвячених виокремленню ролі системи мотивації в стратегічному розвитку підприємства, явно недостатньо. I у зв'язку з цим принципове значення має розроблення і забезпечення системи ефективного управління мотивацією на підприємствах, необхідність якої диктується і наростаючим дефіцитом кадрів, що все реальніше виявляється в умовах стратегічного розвитку.

Виклад основного матеріалу дослідження. Нині ні в кого не викликає сумніву, що найважливішим ресурсом будь-якого підприємства є його співробітники. Однак далеко не всі керівники розуміють, як важко керувати цим ресурсом. Від того, наскільки ефективно налагодити працю співробітників, залежить успіх будь-якого підприємства. Завдання менеджерів полягає в тому, щоб максимально ефективно використовувати можливості персоналу. Якими б сильними не були рішення керівни- 
ків, ефект від них може бути отриманий тільки тоді, коли вони вдало втілені у справи співробітниками підприємства. А це може статися тільки в разі, якщо працівники зацікавлені в результатах своєї праці. Тут ми стикаємося 3 найважливішим аспектом управління - мотивацією.

Виходячи з методології економіки праці, мотивування персоналу досягається шляхом інвестування в людський капітал (або розвиток потенціалу працівників). На основі розвитку теорії людського капіталу, обгрунтованої А. Смітом [4] і розвиненою в другій половині XX ст. нобелівським лауреатом Г. Беккером [5], Я. Мінсер [6, с. 200-202] і Т. Шульцем [7, с. 80-82], стає очевидним, що розвиток людини забезпечується інвестиціями в накопичення знань і навичок, що підвищує кваліфікаційний рівень і підприємницькі здібності, формує необхідний потенціал для відповідного розвитку економіки. 3 погляду менеджменту персоналу, для задоволення таких (відмінних від некваліфікованої і простої праці) потреб персоналу керівник повинен використовувати відповідні методи мотивації, серед яких пріоритетними є ті, що спонукають до задоволення як нематеріальних потреб в отриманні кваліфікації і розвитку, так і матеріальних (отримання бажаного доходу від інноваційної роботи і реалізації інноваційного потенціалу). Однак, як показує проведений контент-аналіз результатів досліджень, саме під час відбору методів мотивації серед учених виникають суттєві суперечності:

- по-перше, науковою проблемою можна визнати той факт, що методи мотивації персоналу до стратегічного розвитку підприємства як об'єкта наукових досліджень залишилися без уваги сучасних учених-економістів;

- по-друге, серед учених-економістів, об'єктом досліджень яких виступає розвиток мотивації персоналу загалом і розвиток мотивації персоналу до стратегічного розвитку, є різні способи вирішення цієї проблеми.

Головним об’єднуючим усі погляди недоліком можна визнати факт, що замість методів для розвитку мотивації описуються фактори, заходи, види, методи стимулювання й інші категорії, що характеризують певні процеси і за призначенням забезпечують цей розвиток. При цьому відбувається плутанина в описі самих процесів щодо об'єкта дослідження. Мотивація включає в себе внутрішній стан людини, названий потребою, і щось поза ним, що визначається як стимул або завдання.

Поведінка людини визначається потребою, яка домінує в цей момент часу. 3 психологічного погляду, потребою є фізіологічні чи психологічні відчуття нестачі чогонебудь. Це те, від чого людина прагне звільнитися, тому що поки потреба існує, вона дає про себе знати і вимагає усунення.

Узагальнюючи вищевикладене, загальну характеристику процесу мотивації можна представити за допомогою взаємодії сукупності потреб, мотивів і цілей, зображених на рис. 1.

Мотивація праці нами розглядається як фактор, що визначає ставлення до праці і робочу поведінку працівника, а потреби - як найважливіші передумови мотивації. В основі мотивації праці лежать не тільки найбільш значущі для працівника потреби, а й те, якою мірою працівник має можливість їх задовольняти, працюючи на цьому підприємстві, і які перспективи їх задоволення він бачить у майбутньому.

Виходячи з вищесказаного, мотивація як інструмент займає особливе місце в системі управління персоналом підприємства. А в ринкових умовах функціонування, коли управління персоналом трансформується в самостійну наукову дисципліну - кадровий менеджмент, у практиці роботи підприємств управління персоналом сформувалося в складну систему менеджменту персоналу з окремими підсистемами, оцінка та мотивація праці персоналу виступає як одна з підсистем цієї системи.

Вирішення завдання ефективного управління персоналом насамперед зводиться до вдосконалення навичок працівників і до вишукування найкращих способів спонукання працівників до результативної роботи. 


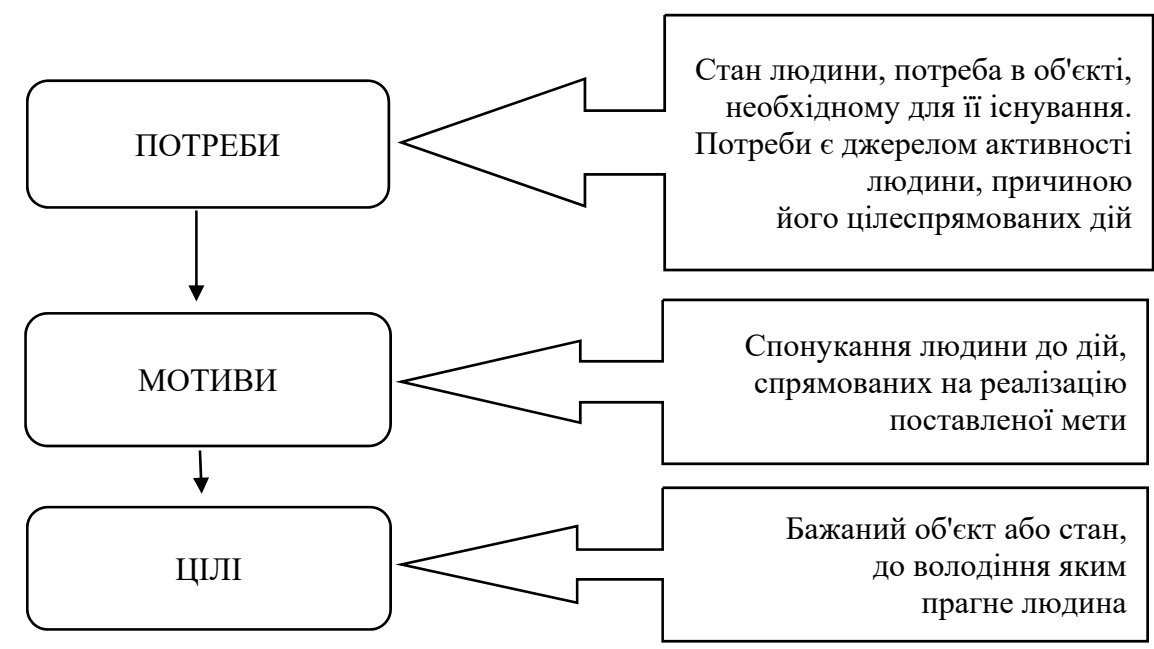

Рис. 1. Характеристика процесу мотивації

Джерело: складено автором за [1-4]

3 огляду на ці фактори, можна зробити таку градацію потенційних співробітників підприємства:

- компетентні та мотивовані;

- мотивовані, але не досить компетентні;

- компетентні, але не досить мотивовані;

- не досить компетентні і не досить мотивовані.

Усі методи мотивації можна згрупувати в чотири стимулюючих види, такі як: економічні; управління за цілями; збагачення праці; система участі.

1. Економічні стимули - це зарплата у всіх іiі різновидах, включаючи контрактну, премії, пільги, страховки, безпроцентні кредити тощо. Успішність їхнього впливу визначається тим, наскільки колектив розуміє принципи системи, визнає їх справедливими, якою мірою дотримується обов'язковість заохочення і невідворотність покарання.

2. Управління за цілями передбачає встановлення для особистості або групи ланцюга цілей, які сприяють вирішенню головного завдання підприємства (досягнення певних кількісних або якісних рівнів, підвищення кваліфікації персоналу тощо). Досягнення кожної мети автоматично означає підвищення рівня зарплати або іншу форму заохочення.

3. Збагачення праці належить до неекономічних методів та означає надання людям більш змістовної, перспективної роботи, значної самостійності у визначенні режиму праці і використанні ресурсів. Важливу роль тут відіграє і зростання соціального статусу.

4. Система участі нині існує в різноманітних формах: від широкого залучення колективу до прийняття рішень із найважливіших проблем виробництва й управління, особливо характерного для Японії, до співучасті у власності шляхом придбання акцій власного підприємства на пільгових умовах.

У межах цих груп методів на вітчизняних підприємствах сьогодні розробляються окремі методики і системи мотивації та стимулювання персоналу.

Як зазначалося раніше, головним інструментом підвищення ефективності використання інтелектуального потенціалу на підприємстві є мотивація. Мотивація дає змогу забезпечити формування компетентного фахівця-професіонала і його найкраще включення в роботу. 
Система мотивації інтелектуальної праці на підприємстві являє собою сукупність взаємопов'язаних елементів (системи оплати праці, заохочення за вислугу років, кар'єрного росту, визнання успіхів тощо) і складається із зовнішньої і внутрішньої мотивації. Зовнішня мотивація спрямована на заохочення результату і процесу інтелектуальної діяльності. Внутрішня мотивація спрямована на створення, збереження потенціалу інтелектуального працівника.

Зовнішня мотивація - конструктор для опису детермінації поведінки в тих ситуаціях, коли фактори, які його ініціюють і регулюють, знаходяться поза «Я» особистості або поза поведінкою людини. Зовнішня мотивація - це засіб досягнення мети. Вона безпосередньо впливає на поведінку, але ефективність ії дії обмежена, поки вона сприймається людиною як стимул або тиск.

Внутрішня мотивація - конструкт, що описує такий тип детермінації поведінки, коли регулюючі його чинники виникають зсередини особистісного «Я» і повністю знаходяться всередині самої поведінки. Внутрішня мотивація - це розуміння сенсу, переконаність. Вона виникає в тому разі, якщо ідея, цілі і завдання, сама діяльність сприймаються як гідні і доцільні.

Значення зовнішньої мотивації для роботи велике. Але внутрішня мотивація в сучасному світі набуває все більшого значення. Вона важлива через її здатність тривалий час впливати на результати праці та ставлення до роботи. Ї̈̈ вплив тим сильніший, чим вищі і різноманітніші вимоги до змісту роботи, чим більше цій зміст відповідає внутрішньому стану людини. Зовнішня мотивація повинна виконувати на початковому етапі роль опори. Для створення системи ефективної праці зовнішню мотивацію можна також розглядати як додатковий підтримуючий стимул у період консолідації. Однак довгострокова мотивація й ефективні зміни в поведінці співробітників досягаються тільки за умови створення внутрішньої мотивації.

На нашу думку, система мотивації повинна містити: мотивацію, спрямовану на підвищення інтелектуального потенціалу; мотивацію, спрямовану на ефективну комунікацію; мотивацію, спрямовану на підвищення компетенцій, та мотивацію, спрямовану на підвищення результатів праці. Мотивація, спрямована на підвищення інтелектуального потенціалу, може включати такі форми стимулювання, як участь в управлінні, моральні, кар'єра і розвиток, патерналізм. У таку форму стимулювання, як кар'єра і розвиток, можуть входити: компенсація витрат на освіту, чітке розуміння перспектив кар'єрного росту, систематичне підвищення кваліфікації тощо. У моральну форму стимулювання можуть входити: конкурси спеціальностей, систематичне заохочення кращих співробітників почесними знаками, присутність на дошці пошани тощо. Залучення до співволодіння й участі в управлінні може здійснюватися за участю в прибутках, участю в акціонерному капіталі, самостійному розпорядженні бюджетом підрозділу тощо. Інструментами патерналізму можуть бути: додаткове соціальне і медичне страхування, оплата короткочасної чи довготривалої непрацездатності, оплачувана відпустка, оплата медичного обслуговування працівників тощо.

Мотивація, спрямована на ефективну комунікацію, включає організаційні форми стимулювання. До організаційних форм стимулювання належать: забезпечення працівників робочим одягом і взуттям, ефективна програма інформаційного забезпечення, система збереження, передачі та обміну інформацією, створення об'єднань співробітників з метою вирішення конкретних завдань тощо.

Мотивація, спрямована на підвищення компетенцій, включає грошові та натуральні форми стимулювання. Інструментами, що стимулюють підвищення компетенції, можуть бути премії за освоєння програмних продуктів, премії за рейтингом ефективності співробітників підрозділу, премії за репутацію, а також оплата транспортних витрат, доплата на харчування, оплата харчування, знижки на покупку товарів (продукції компанії), автомобіль, що надається компанією тощо. 
Мотивація, спрямована на підвищення результатів праці, включає грошові форми стимулювання. Інструментами, що стимулюють підвищення результатів праці, можуть бути заробітна плата, премія за продуктивність, премія за якість продукції тощо.

Запропонована система мотивації персоналу підприємства дасть змогу підвищити ефективність діяльності та забезпечити стратегічний розвиток підприємства.

Висновки. Система мотивації в стратегічному розвитку підприємства по-винна включати не тільки зовнішню мотивацію, а й умови для внутрішньої мотивації персоналу. Багато підприємств під час створення системи мотивації абсолютно не приділяють уваги внутрішній мотивації, припускаючи, що персонал, укладаючи трудовий договір перед прийняттям, уже нею володіють. Навіть якщо персонал під час найму володів цією мотивацією, без належного підтримання внутрішня мотивація може зникнути. Зовнішня мотивація в основному спрямована на оплату та заохочення результату праці. Система мотивації, орієнтована тільки на зовнішню мотивацію, тобто оплату за результат, неминуче призведе до зниження якості інтелектуальної праці. За стратегічного розвитку підприємства, які не підвищують якості своєї продукції, не зможуть конкурувати на ринку. Внутрішня мотивація спрямована на створення, збереження i розвиток творчого інтелектуального потенціалу співробітників підприємства. Тільки внутрішня мотивація дає змогу поліпшувати якість продукції, тим самим підвищувати конкурентоспроможність усього підприємства. У системі мотивації сучасних підприємств внутрішня і зовнішня мотивації повинні бути збалансовані.

Таким чином, комплексна система мотивації, що включає внутрішню і зовнішню мотивацію персоналу, спрямована на створення і застосування ними спеціалізованих знань, $є$ ефективним інструментом активізації стратегічного розвитку підприємства.

\section{Список використаних джерел:}

1. Базалійська Н.П., Казановська М.П. Стан системи мотивації персоналу на вітчизняних підприємствах. Інноваційна економіка. 2013. № 5. С. 103-105.

2. Калініченко А.В. Мотивація та мотиваційний процес: сутність та поняття. Вісник економіки транспорту і промисловості. 2013. № 42. С. 417-420.

3. Колот Л. М. Мотивація персоналу: підручник. Київ : КНЕУ, 2002. 345 с.

4. Корицкий А.В. Истоки и основные положения теории человеческого капитала. Креативная экономика. 2007. № 5 (5). С. 3-10.

5. Becker Gary S. Human Capital: A Theoretical and Empirical Analysis, with Special Reference to Education. 2d ed. New York : Columbia University Press for NBER, 1975.

6. Great Economists since Keynes: An introduction to the lives \& works of one handred great economists of the past. 2009. СПб. : Экономикус, $384 \mathrm{c}$.

7. Schultz T.W. The Economic Value of Education. 1963. New York : Colambia University Press. 89 p.

\section{References:}

1. Bazaliyska N.P., Kazanovska M.P. (2013) Stan systemy motyvatsiyi personalu na vitchyznyanykh pidpryyemstvakh [The state of the system of staff motivation at domestic enterprises]. Innovatsiyna ekonomika, no. 5, pp. 103-105.

2. Kalinichenko A.V. (2013) Motyvatsiya ta motyvatsiynyy protses: sutnist ta ponyattya [Motivation and motivational process: essence and concept]. Visnyk ekonomiky transportu i promyslovosti, no. 42 , pp. $417-420$.

3. Kolot L.M. (2020) Motyvatsiya personalu: pidruchnyk [Motivation of staff: a textbook]. Kyiv: KNEU. 345 pp.

4. Koritskiy A.V. (2007) Istoki i osnovnyye polozheniya teorii chelovech-eskogo kapitala [The origins and main provisions of the theory of human capital]. Kreativnaya ekonomika, no. 5, pp. 3-10.

5. Becker Gary S. (1975) Human Capital: A Theoretical and Empirical Analysis, with Special Reference to Education. 2d ed. New York: Columbia University Press for NBER.

6. Great Economists since Keynes: An introduction to the lives \& works of one handred great economists of the past. (2009) SPb .: Economikus. 384 p.

7. Schultz T.W. (1963) The Economic Value of Education. New York: Colambia University Press. 89 p. 